\title{
Analysis of Relationship Between Imaging Features of Aortic Dissection and Blood Parameters
}

\author{
Aort Diseksiyon Görüntü Özellikleri ile Kan Parametreleri Arasındaki ilişki
}

\author{
- Abdullah Algın, ๑ Hatice Şeyma Akça, ๑ Serdar Özdemir, ๑ Mustafa Ahmet Afacan*, \\ - Serkan Emre Eroğlu \\ University of Health Sciences Turkey, Ümraniye Training and Research Hospital, Clinic of Emergency Medicine, Istanbul, Turkey \\ *University of Health Sciences Turkey, Haydarpasa Numune Training and Research Hospital, Clinic of Emergency Medicine, Istanbul, Turkey
}

\section{Abstract}

Aim: Aimed to evaluate the relationship of serum biochemical and blood parameters with aortic rupture and dissection types according to the DeBakey classification.

Methods: Forty-three patients, who were admitted to the emergency department between 01.01.2011 and 01.01.2019 with the diagnosis of aortic dissection, were retrospectively evaluated. Gender, age, symptoms at presentation, vital parameters, creatinine and, troponin levels, and hemogram parameters were recorded after blood tests. Neutrophil-tolymphocyte ratio and monocyte-to-platelet ratio were obtained from these values. These results were compared with the presence of aortic rupture and the DeBakey classification.

Results: Of the 43 patients included in the study, 30 were male $(69.8 \%)$, and 13 were female $(30.2 \%)$. Aortic rupture was seen in two of the 30 male patients $(6.7 \%)$ and none of the females $(p=1.000)$. There was a significant difference only in blood urine nitrogen and monocyte-to-platelet ratio between patients with and without aortic rupture ( $p=0.035$ and $p=0.015$, respectively).

Conclusion: Most of the routinely evaluated blood and biochemical parameters in aortic dissection cases did not yield significant results in comparison to the DeBakey classification and the presence of rupture. Only blood urea nitrogen and monocyte-to-platelet ratio values were lower in patients with aortic rupture.

Keywords: Aortic dissection, DeBakey classification, aortic rupture, biochemical marker, emergency medicine
Öz

Amaç: Acil servise başvuran ve aort diseksiyonu tanısı alan hastalarda serum biyokimya ve kan parametrelerinin aort rüptür varlığı ile DeBakey sınıflaması diseksiyon tipleriyle ilişkisinin değerlendirilmesi amaçlandı.

Yöntemler: Acil servise 01.01.2011 ve 01.01.2019 tarihleri arasında aort diseksiyonu tanısı ile başvuran 43 hasta retrospektif olarak değerlendirildi. Cinsiyet, yaş, başvuru anındaki semptomlar, sistolik ve diyastolik kan basıncı, nabız, kan üre azotu, kreatinin, troponin, hemoglobin, hematokrit, beyaz kan hücresi sayımı, monosit, nötrofil, lenfosit, trombosit sayısı, ortalama trombosit hacmi ve kırmızı hücre dağılımı kaydedildi. Bu değerlerden nötrofil-lenfosit oranı ve monosit-trombosit oranı elde edildi. Bu sonuçlar aort rüptürü varlığı ve DeBakey sınıflandırması ile karşılaştırıldı.

Bulgular: Çalışmaya alınan 43 hastanın 30'u erkek $(\% 69,8)$, 13 'ü kadındı $(\% 30,2)$. Aort rüptüründe 30 erkek olgunun ikisinde $(\% 6,7)$ rüptür görüldü ve kadın olguların hiçbirinde rüptür gözlenmedi $(p=1,000)$. Sadece kan üre azotu ve monosittrombosit oranı değerleri aort rüptüründe anlamlı farklılık gösterdi (sırasıyla $p=0,035$ ve $p=0,015$ ).

Sonuç: Aort diseksiyonu olgularında rutin olarak değerlendirilen kan ve biyokimya parametrelerinin çoğu DeBakey sınıflandırması ve rüptür varlığı ile karşılaştırıldığında anlamlı sonuç vermedi. Aort rüptürü olan hastalarda düşük olan kan üre azotu ve monosit-trombosit oranı değerleri anlamlıydı.

Anahtar Sözcükler: Aort diseksiyonu, DeBakey sınıflandırması, aort rüptürü, biyokimyasal belirteç, acil tıp
Address for Correspondence/Yazışma Adresi: Abdullah Algın, University of Health Sciences of Turkey, Ümraniye Training and Research Hospital, Clinic of Emergency Medicine, İstanbul, Turkey E-mail: dralgin@hotmail.com ORCID: orcid.org/0000-0002-9016-9701

Received/Geliş Tarihi: 25 November 2019 Accepted/Kabul Tarihi: 24 February 2020
${ }^{-}$Copyright 2020 by The Medical Bulletin of istanbul Haseki Training and Research Hospital The Medical Bulletin of Haseki published by Galenos Yaynevi. ${ }^{8}$ Telif Hakkı 2020 istanbul Haseki Eğtitim ve Araş̧trma Hastanesi Haseki Tip Bülteni, Galenos Yayinevi tarafindan yayinlanmıştr. 


\section{Introduction}

Aortic dissection is a cardiovascular disease that has high mortality and morbidity. Typical signs and symptoms include chest pain, back pain, syncope, and neurological symptoms. The rate of mortality within the first 24 hours in untreated cases is $21 \%$ (1). Acute aortic dissection results in mortality in $20 \%$ of patients before admission to emergency department, in 30\% in the hospital, and in $20 \%$ within ten years after discharge (1). There are often underlying pathologies, such as arteriosclerosis and hypertension, and the incidence increases due to these entities $(1,2)$. Risk factors for acute aortic dissection include age, hypertension and, Marfan syndrome. Aortic dissection usually occurs at a younger age in patients with Marfan syndrome than in others. In the pathogenesis of aortic dissection, firstly, cystic medial necrosis develops. Cystic medial necrosis is characterized by destruction of elastic tissue and accumulation of proteoglycans and apoptosis of smooth muscle cells in the media layer leading to, aortic dilatation, dissection and aortic wall rupture (3).

It is known that the diagnosis of aortic dissection with imaging methods can be made with 95-98\% specificity and $98-100 \%$ sensitivity $(3,4)$. Besides, some biochemical tests that can be used for diagnostic purposes as a contribution to these imaging methods have been reported in the literature $(3,5)$. Smooth muscle myosin heavy chain, creatinine kinase BB isoenzyme, calponin, elastin, and transforming growth factor (TGF)beta are some of the biomarkers that may be used $(3,4)$. It is claimed that these markers can be used for triage, in the distinction of acute-chronic dissection, or to rule out acute myocardial infarction that has a similar presentation (3).

Biochemical markers have been evaluated as diagnostic or mortality indicators for aortic dissection in the literature. On the other hand, the relationship between biochemical markers and clinical conditions, such as location of dissection and development of aortic rupture, that may affect prognosis have not been reported in the literature. In this study, it is aimed to evaluate the relationship between routine biochemical markers and such clinical conditions in patients admitted to the emergency department and diagnosed with aortic dissection.

\section{Methods}

In this study, 47 patients, who were admitted to the emergency department between 01.01.2011 and 01.01.2019 with the diagnosis of aortic dissection established by computed tomography (CT) angiography, were retrospectively evaluated. Ethics committee approval dated 04.09.2019 and numbered 170 was obtained from the University of Health Sciences Ümraniye Training and Research Hospital Ethics Committee (September $4^{\text {th }} 2019,170$ ) before the study. Four patients whose images of the CT angiography or biochemical parameters could not be obtained were excluded, and the remaining 43 patients were included in the study.

Demographic data, such as gender and age, symptoms at presentation, systolic and diastolic blood pressure, and pulse were recorded. In addition, blood urine nitrogen (BUN), creatinine, troponin, hemoglobin $(\mathrm{Hb})$ and, hematocrit (Hct) levels, white blood cell count (WBC), monocyte, neutrophil, lymphocyte and platelet (Plt) counts, mean platelet volume (MPV), and red cell distribution width (RDW) values were recorded after blood tests. Neutrophil-to-lymphocyte ratio (NLR) and monocyte-to-platelet ratio (MPR) were obtained from these values.

Radiological images of the patients were retrospectively evaluated by a radiologist with a 7-yearexperience in CT interpretation. The patients were also classified according to the DeBakey classification and presence of aortic rupture were noted according to the radiological images.

\section{Statistical Analysis}

The IBM SPSS Statistics version 21.0 (New York, United States) software was used for statistical analysis. Categorical data were expressed as numbers and percentages and mean and standard deviation were used for the expression of numerical data with normal distribution, and median, minimum and maximum values were used for nonparametric numeric data with no normal spatial distribution. The distribution of numerical data was evaluated by the Shapiro-Wilk test. A chi-square test was used to evaluate the relationship between categorical data. Student's t-test was used for comparison of the normally distributed numerical data between the two groups and the Mann-Whiney $U$ test was used for comparison of the nonparametric numerical data between the two groups. The Kruskal-Wallis test was used for comparison of nonparametric numerical data if there were more than two groups. A p value of less than 0.05 was considered statistically significant.

\section{Results}

Of the 43 cases included in the study, 30 were male $(69.8 \%)$, and 13 were female $(30.2 \%)$. The most common symptoms were chest pain in 11 patients $(25.6 \%)$, dyspnea in seven $(16.3 \%)$, back pain in five $(11.6 \%)$, abdominal pain in three $(7 \%)$, low back pain in two $(4.7 \%)$, myalgia in two $(4.7 \%)$, syncope in two $(4.7 \%)$, and epigastric pain in two patients (4.7\%). Also, 
symptoms such as aphasia, non-specific pain, foot pain, headache, purple discoloration of the skin, pneumonia, flank pain, and inability to walk were observed in one patient (2.3\%). According to the DeBakey classification, type 1 aortic dissection was observed in 16 (37.2\%), type 2 aortic dissection in four (9.3\%), and type 3 aortic dissection in 23 patients (53.5\%). In two cases (4.7\%), aortic rupture was observed on CT angiography. Descriptive statistics of the numerical data are summarized in Table 1.

According to the DeBakey classification, type 1 dissection was present in $40 \%$ of 30 male patients, type 2 dissection in $6.7 \%$ and type 3 dissection in $53.3 \%$. In the 13 female patients, type 1 dissection was present in $30.8 \%$, type 2 dissection in $15.4 \%$, and type 3 aortic dissection in $53.8 \%$. There was no significant relationship between gender and the type of dissection according to the DeBakey classification $(p=0.622)$. Aortic rupture was seen in two of 30 male patients (6.7\%), and no rupture was observed in any of the female patients. The relationship between gender

\begin{tabular}{|c|c|c|}
\hline \multicolumn{3}{|l|}{ Parametric data } \\
\hline & Mean & \pm Standard deviation \\
\hline $\begin{array}{l}\text { Blood pressure-systole } \\
(\mathrm{mmHg})\end{array}$ & 138.56 & \pm 42.02 \\
\hline $\begin{array}{l}\text { Blood pressure-diastole } \\
(\mathrm{mmHg})\end{array}$ & 78.81 & \pm 19.8 \\
\hline Pulse (/min) & 84.51 & \pm 22.8 \\
\hline WBC $\left(\times 10^{3} / \mu \mathrm{L}\right)$ & 10.03 & \pm 3.6 \\
\hline Monocyte $\left(\times 10^{3} / \mu \mathrm{L}\right)$ & 0.65 & \pm 0.28 \\
\hline MPV (fL) & 8.29 & \pm 1.78 \\
\hline RDW (\%) & 15.92 & \pm 1.83 \\
\hline \multicolumn{3}{|l|}{ Nonparametric data } \\
\hline & Median & Minimum-maximum \\
\hline Age & 60 & $26-88$ \\
\hline BUN (mg/dL) & 42.8 & $21.4-228.98$ \\
\hline Creatinine (mg/dL) & 0.98 & $0.55-9.11$ \\
\hline Troponin (ng/dL) & 0.012 & $0-0.53$ \\
\hline $\mathrm{Hb}(\mathrm{g} / \mathrm{dL})$ & 12.8 & 7.4-35.4 \\
\hline Htc $(\%)$ & 39.1 & $10.7-48.2$ \\
\hline Neutrophil $\left(\times 10^{3} / \mu \mathrm{L}\right)$ & 6.74 & $2.18-14.9$ \\
\hline Lymphocyte $\left(\times 10^{3} / \mu \mathrm{L}\right)$ & 2.29 & $0.6-5.16$ \\
\hline Platelet $\left(\times 10^{3} / \mu \mathrm{L}\right)$ & 226 & $104-539$ \\
\hline NLR & 3.6 & $0.92-10.82$ \\
\hline MPR & 0.039 & $0.01-0.09$ \\
\hline \multicolumn{3}{|c|}{$\begin{array}{l}\text { WBC: White blood cell, MPV: Mean platelet volume, RDW: Red cell distribution } \\
\text { width, BUN: Blood area nitrogen, Hb: Hemoglobin, Htc: Hematocrit, NLR } \\
\text { Neutrophil to lymphocyte ratio, MPR: Monocyte-to-platelet ratio }\end{array}$} \\
\hline
\end{tabular}

and presence of aortic rupture was not statistically significant $(p=1.000)$.

There was a significant difference between males and females in Hct and creatinine values, which were both lower in the female group $(p=0.01$ and $p<0.0001$, respectively). There was no statistically significant difference in other parameters between males and females (Table 2).

In the comparison of aortic rupture with numerical data, the relationship between BUN and aortic rupture was statistically significant $(p=0.035)$. Additionally, a statistically significant relationship between MPR values and aortic rupture was detected ( $p=0.015$, respectively). According to these results, BUN and MPR values were significantly lower in patients with aortic rupture. No significant relationship was found between aortic rupture and the remaining numerical data (systolic and diastolic blood pressures, pulse, WBC, monocyte, MPV, RDW, age, creatinine, troponin, $\mathrm{Hb}$, Hct, neutrophil, lymphocyte, platelet, and NLR) (Table 3).

No significant correlation was found between DeBakey classification and numerical data (systolic and diastolic blood pressures, pulse, WBC, monocyte, MPV, RDW, MPR, age, creatinine, BUN, troponin, $\mathrm{Hb}, \mathrm{Hct}$, neutrophil, lymphocyte, Plt, and NLR) (Table 4).

\section{Discussion}

Aortic dissection is a potentially lethal clinical entity. Radiological methods, especially CT angiography, are used for diagnosis. CT angiography provides information not only in the diagnosis of cases but also in different features of dissection, such as location, type of dissection, and the status of the affected solid organs (6). In recent years, there have been an increasing number of biochemical parameters that may be useful in the diagnosis of aortic dissection in centers that do not have $\mathrm{CT}$ angiography or may be used for triage before imaging even if angiography is available. In this study, biochemical and blood parameters are compared with the DeBakey classification, gender, and presence of aortic rupture in 43 patients with aortic dissection. As a result, no significant relationship was found between the DeBakey classification and any of the numerical parameters, and BUN and MPR values were found to be statistically significantly lower in cases with aortic rupture. In comparison biochemical parameters with gender, creatinine and Hct values were found to be statistically lower in the female group, and no significant correlation was found between gender and other numerical data.

The use of biochemical markers in cardiac pathologies is particularly common in acute myocardial infarction, and its origin dates back to the 1950s (1). For the 
diagnosis of aortic dissection, imaging methods are more prominent, and it is known that aortic dissection can be diagnosed by imaging with $95-98 \%$ specificity and 98-100\% sensitivity. In this context, diagnostic imaging methods are reliable. However, biochemical markers may be used in cases where urgent CT examination cannot be performed, in order to exclude acute myocardial infarction in cases with similar presentation i.e., chest pain, or for triage in the determination of patients requiring urgent imaging. In its pathogenesis, cystic medial necrosis, characterized by destruction of elastic tissue, accumulation of proteoglycans and apoptosis of smooth muscle cells in the media layer is followed by aortic dilatation, dissection, and aortic wall rupture. After the dissection, smooth muscle-derived proteins that arise from apoptosis of smooth muscles in the media layer get into the circulation (3). Smooth muscle myosin heavy chain, creatinine kinase BB isoenzyme and, calponin are among these proteins which can be used as a marker of dissection $(3,4)$. A rapid 30-minute assay of smooth muscle myosin heavy chain has been shown to be successful in the diagnosis of acute aortic dissection with $97 \%$ specificity (5). Elastin, which is a crucial component of the aortic wall structure, inflammatory markers, such as CRP, matrix metalloproteinases, TGFbeta, and D-dimer, are also some biomarkers that can be used in the diagnosis $(3,4)$.

Low levels of total cholesterol have been shown to be associated with increased in-hospital mortality in patients with Stanford type A aortic dissection (2). This negative correlation has also been shown in different diseases such as acute coronary syndrome and acute heart failure and is called cholesterol paradox $(7,8)$. In this study, no analysis of mortality was made, and cholesterol level was not evaluated.

Levčík et al. (9) showed that D-dimer levels above $0.5 \mathrm{mg} / \mathrm{L}$ could be used in the diagnosis of acute aortic dissection with $100 \%$ sensitivity, $100 \%$ negative predictive value, $37 \%$ specificity, $65 \%$ positive predictive value, and $71 \%$ accuracy. According to this result, D-dimer level below $0.5 \mathrm{mg} / \mathrm{L}$ can be used to exclude aortic dissection. Therefore, D-dimer can be used in the diagnosis of aortic dissection for exclusion and triage purposes $(9,10)$.

\begin{tabular}{|c|c|c|c|c|c|}
\hline & \multicolumn{2}{|l|}{ Male } & \multicolumn{2}{|l|}{ Female } & \\
\hline \multicolumn{6}{|l|}{ Parametric data } \\
\hline & Mean & \pm Standard deviation & Mean & \pm Standard deviation & $\mathbf{p}$ \\
\hline Blood pressure-systole $(\mathrm{mmHg})$ & 140.1 & \pm 45.11 & 135 & \pm 35.26 & 0.719 \\
\hline Blood pressure-diastole $(\mathrm{mmHg})$ & 77.27 & \pm 20.68 & 82.38 & \pm 17.81 & 0.443 \\
\hline Pulse (/min) & 86.57 & \pm 24.1 & 79.77 & \pm 19.52 & 0.376 \\
\hline WBC $\left(\times 10^{3} / \mu \mathrm{L}\right)$ & 10.52 & \pm 3.95 & 8.91 & \pm 2.41 & 0.18 \\
\hline Monocyte $\left(\times 10^{3} / \mu \mathrm{L}\right)$ & 0.67 & \pm 0.29 & 0.6 & \pm 0.24 & 0.462 \\
\hline MPV (fL) & 8.34 & \pm 1.95 & 8.17 & \pm 1.33 & 0.783 \\
\hline RDW (\%) & 15.94 & \pm 15.88 & 15.87 & \pm 1.54 & 0.911 \\
\hline \multicolumn{6}{|l|}{ Nonparametric data } \\
\hline & Median & Minimum-maximum & Median & Minimum-maximum & \\
\hline Age & 59.5 & $46-86$ & 65 & $26-88$ & 0.764 \\
\hline BUN (mg/dL) & 42.8 & $21.4-229$ & 38.5 & $21.4-57.8$ & 0.522 \\
\hline Creatinine $(\mathrm{mg} / \mathrm{dL})$ & 1.07 & $0.77-9.11$ & 0.84 & $0.55-1$ & $<0.0001$ \\
\hline Troponin (ng/dL) & 0.0135 & $0-0.53$ & 0.006 & $0-0.16$ & 0.636 \\
\hline Hemoglobin $(g / d L)$ & 13.4 & 7.4-15.7 & 12.3 & 9.69-35.4 & 0.159 \\
\hline Hematocrit (\%) & 40.35 & $24.6-48.2$ & 37.3 & $10.7-41$ & 0.01 \\
\hline Neutrophil $\left(x 10^{3} / \mu \mathrm{L}\right)$ & 6.74 & $3.05-14.9$ & 6.17 & $2.18-10.17$ & 0.158 \\
\hline Lymphocyte $\left(\times 10^{3} / \mu \mathrm{L}\right)$ & 2.1 & 0.6-5.16 & 2.5 & $0.68-3.74$ & 0.63 \\
\hline Platelet $\left(\times 10^{3} / \mu \mathrm{L}\right)$ & 225 & $106-539$ & 229 & $104-287$ & 0.744 \\
\hline NLR & 3.055 & $1.08-8.51$ & 2.24 & $0.92-10.82$ & 0.313 \\
\hline MPR & 0.039 & $0.01-0.09$ & 0.039 & $0.02-0.07$ & 0.868 \\
\hline
\end{tabular}


In a study conducted by Guan et al. (11), it was showed that preoperative low fibrinogen level was associated with neurological complications in patients with acute aortic dissection. It is thought that this may be secondary to large amounts of fibrinogen getting into the circulation and fibrin deposition. Meng et al. (12) found that fructosamine and Hba1c were related to thoracic aortic dissection. These markers have been suggested to be risk factors for the development of thoracic aortic dissection. In a study by Liu et al. (13), low $\mathrm{HDL}$ values were shown to be associated with mortality in aortic dissection cases. In their study, Sbarouni et al. (14) found no relationship between ischemia-modified albumin and acute aortic dissection. These biochemical parameters are not among the parameters evaluated in this study.

In previous studies, an increase in NLR level was shown to be associated with increased mortality in patients with Stanford type B and DeBakey type 1 acute aortic dissection $(15,16)$. In this study, although higher NLR values were obtained in DeBakey type 2 cases compared to other types, the difference was not statistically significant $(p=0.549)$. High platelet-to-lymphocyte ratio has also been shown to be associated with mortality in patients with Stanford type B aortic dissection, which was not evaluated in this study (17).

\section{Study Limitations}

This study has some limitations. First, the role of parameters in the diagnosis of aortic dissection could not be evaluated because there was no control group without aortic dissection. Besides, the limited number of patient groups constitutes the weakness of the study, and only two cases of aortic rupture limit the evaluation of biochemical parameters especially in the diagnosis of rupture. Another limitation is the retrospective design of the study.

\section{Conclusion}

Most of the routinely evaluated blood and biochemical parameters in aortic dissection cases did not yield significant results in comparison to the DeBakey classification and the presence of rupture. The only significant parameters were BUN and MPR values which were lower in patients with rupture. Further large-scale prospective multicenter studies are warranted.

\begin{tabular}{|c|c|c|c|c|c|}
\hline & \multicolumn{2}{|c|}{ Aortic rupture absent } & \multicolumn{2}{|c|}{ Aortic rupture present } & \multirow[b]{2}{*}{$p$} \\
\hline & Median & Minimum-maximum & Median & Minimum-maximum & \\
\hline Blood pressure-systole $(\mathrm{mmHg})$ & 138 & $65-270$ & 107.5 & $80-135$ & 0.29 \\
\hline Blood pressure-diastole $(\mathrm{mmHg})$ & 78 & $40-122$ & 62 & $40-84$ & 0.223 \\
\hline Pulse (/min) & 80 & $45-150$ & 109 & 95-123 & 0.121 \\
\hline WBC $\left(\times 10^{3} / \mu \mathrm{L}\right)$ & 9.66 & $4.2-18.7$ & 11.76 & 7.6-15.9 & 0.496 \\
\hline Monocyte $\left(\times 10^{3} / \mu \mathrm{L}\right)$ & 0.61 & $0.03-1.31$ & 0.54 & $0.35-0.72$ & 0.569 \\
\hline MPV (fL) & 8.4 & $5.25-13.2$ & 7.51 & 7.1-7.92 & 0.532 \\
\hline RDW (\%) & 15.8 & $12.7-22.1$ & 14.55 & $14.3-14.8$ & 0.283 \\
\hline Age & 60 & $26-88$ & 58 & $49-67$ & 0.602 \\
\hline BUN (mg/dL) & 42.8 & 21.4-229 & 24.9 & $22-27.8$ & 0.035 \\
\hline Creatinine $(\mathrm{mg} / \mathrm{dL})$ & 0.98 & $0.55-9.11$ & 0.99 & $0.84-1.13$ & 0.842 \\
\hline Troponin (ng/dL) & 0.0125 & $0-0.53$ & - & - & - \\
\hline Hemoglobin (g/dL) & 12.6 & 7.4-35.4 & 13.95 & 13.8-14.1 & 0.179 \\
\hline Hematocrit (\%) & 39 & $10.7-48.2$ & 41.75 & $40.3-43.2$ & 0.268 \\
\hline Neutrophil $\left(x 10^{3} / \mu \mathrm{L}\right)$ & 6.53 & 2.18-14.9 & 8.09 & 5.58-10.6 & 0.5 \\
\hline Lymphocyte $\left(\times 10^{3} / \mu \mathrm{L}\right)$ & 2.29 & $0.6-5.16$ & 2.76 & $1.32-4.21$ & 0.683 \\
\hline Platelet $\left(\times 10^{3} / \mu \mathrm{L}\right)$ & 226 & $104-425$ & 373 & $208-539$ & 0.465 \\
\hline NLR & 2.86 & $0.92-10.82$ & 3.38 & $2.52-4.23$ & 0.8 \\
\hline MPR & 0.039 & 0.01-0.09 & 0.026 & $0.01-0.04$ & 0.015 \\
\hline
\end{tabular}


Algın et al. Blood Parameters in Aortic Dissection

\begin{tabular}{|c|c|c|c|c|c|c|c|}
\hline DeBakey Classification & \multicolumn{2}{|l|}{ Type 1} & \multicolumn{2}{|l|}{ Type 2} & \multicolumn{2}{|l|}{ Type 3} & \multirow{3}{*}{$\mathbf{p}$} \\
\hline \multicolumn{7}{|l|}{ Parametric data } & \\
\hline & Mean & $\begin{array}{l} \pm \text { Standard } \\
\text { deviation }\end{array}$ & Mean & $\begin{array}{l} \pm \text { Standard } \\
\text { deviation }\end{array}$ & Mean & $\begin{array}{l}\text { 士 Standard } \\
\text { deviation }\end{array}$ & \\
\hline Blood pressure-systole $(\mathrm{mmHg})$ & 133.8 & \pm 46.05 & 120 & \pm 36.29 & 145.01 & \pm 40.28 & 0.474 \\
\hline Blood pressure-diastole $(\mathrm{mmHg})$ & 73.5 & \pm 19.96 & 80 & \pm 23.85 & 82.3 & \pm 19.11 & 0.4 \\
\hline Pulse (/min) & 81.5 & \pm 23 & 105.3 & \pm 43.3 & 83 & \pm 17 & 0.159 \\
\hline WBC $\left(\times 10^{3} / \mu \mathrm{L}\right)$ & 10.64 & \pm 3.68 & 9.26 & \pm 1.87 & 9.75 & \pm 3.82 & 0.687 \\
\hline Monocyte $\left(\times 10^{3} / \mu \mathrm{L}\right)$ & 0.69 & \pm 0.29 & 0.59 & \pm 0.22 & 0.62 & \pm 0.28 & 0.691 \\
\hline MPV (fL) & 8.32 & \pm 1.79 & 7.42 & \pm 1.15 & 8.42 & \pm 1.87 & 0.59 \\
\hline RDW (\%) & 15.86 & \pm 1.47 & 14.53 & \pm 1.3 & 16.21 & \pm 2.06 & 0.237 \\
\hline Nonparametric data & & & & & & & \\
\hline & Median & $\begin{array}{l}\text { Minimum- } \\
\text { maximum }\end{array}$ & Median & $\begin{array}{l}\text { Minimum- } \\
\text { maximum }\end{array}$ & Median & $\begin{array}{l}\text { Minimum- } \\
\text { maximum }\end{array}$ & \\
\hline Age & 57 & $26-83$ & 73.5 & $67-88$ & 60 & $46-86$ & 0.051 \\
\hline BUN (mg/dL) & 38.5 & $23.54-68.5$ & 47.2 & $22-57.8$ & 44.9 & $21.4-229$ & 0.607 \\
\hline Creatinine (mg/dL) & 1.07 & $0.55-1.44$ & 0.96 & $0.84-1.69$ & 0.98 & $0.63-9.11$ & 0.658 \\
\hline Troponin (ng/dL) & 0.0065 & $0-0.53$ & 0.03 & $0.03-0.04$ & 0.014 & $0-0.48$ & 0.129 \\
\hline Hemoglobin $(g / d L)$ & 12.7 & $9.5-15.4$ & 12.6 & $9.91-14.2$ & 12.8 & $7.4-15.7$ & 0.997 \\
\hline Hematocrit (\%) & 38.85 & $10.7-44.2$ & 37.7 & $30.8-43.2$ & 39.1 & $4.2-18.7$ & 0.546 \\
\hline Neutrophil $\left(x 10^{3} / \mu \mathrm{L}\right)$ & 7.95 & $2.18-13$ & 5.81 & $4.85-10.17$ & 6.19 & $2.6-14.9$ & 0.846 \\
\hline Lymphocyte $\left(\times 10^{3} / \mu \mathrm{L}\right)$ & 2.48 & $0.97-5.16$ & 1.59 & $0.94-2.61$ & 2.5 & $0.6-4.77$ & 0.342 \\
\hline Platelet $\left(\times 10^{3} / \mu \mathrm{L}\right)$ & 222 & $104-425$ & 266.5 & $171-539$ & 224 & $137-393$ & 0.529 \\
\hline NLR & 2.81 & $1.08-7.85$ & 3.74 & $1.86-10.82$ & 2.7 & $0.92-8.51$ & 0.549 \\
\hline MPR & 0.04 & $0.01-0.09$ & 0.028 & $0.01-0.05$ & 0.039 & $0.02-0.08$ & 0.371 \\
\hline
\end{tabular}

\section{Authorship Contributions}

Concept: A.A., H.Ş.A. Design: A.A. Supervision: A.A. Data collection and/or processing: A.A. Analysis and/or interpretation: H.Ş.A., S.Ö., S.E.E. Literature searching: A.A., M.A.A. Writing: A.A.

Conflict of Interest: The authors declare no any conflict of interest regarding this study.

Financial Disclosure: The authors declared that this study received no financial support.

\section{References}

1. Suzuki T, Katoh H, Nagai R. Biochemical diagnosis of aortic dissection: from bench to bedside. Japanese heart journal 1999;40:527-34.

2. Liu $X$, Su $X$, Zeng $H$. Impact of admission serum total cholesterol level on in-hospital mortality in patients with acute aortic dissection. Pakistan journal of medical sciences 2016;32:939.
3. Suzuki T, Bossone E, Sawaki $D$, et al. Biomarkers of aortic diseases. American Heart Journal 2013;165:15-25.

4. Bossone E, Suzuki T, Eagle K, Weinsaft J. Diagnosis of acute aortic syndromes. Herz 2013;38:269-76.

5. Suzuki $T$, Katoh $H$, Watanabe $M$, et al. Novel biochemical diagnostic method for aortic dissection: results of a prospective study using an immunoassay of smooth muscle myosin heavy chain. Circulation 1996;93:1244-9.

6. Sariaydin M, Algin A, Bilge Z. A case of Acute Pancreatitis and Acute Renal Failure Due to Aortic Dissection. Journal of Turgut Ozal Medical Center 2017;24.

7. Velavan P, Huan Loh P, Clark A, Cleland JG. The cholesterol paradox in heart failure. Congestive Heart Failure 2007;13:336-41.

8. Cho $\mathrm{KH}$, Jeong $\mathrm{MH}$, Ahn $\mathrm{Y}$, et al. Low-density lipoprotein cholesterol level in patients with acute myocardial infarction having percutaneous coronary intervention (the cholesterol paradox). The American journal of cardiology 2010;106:1061-8. 
9. Levčík M, Kettner J, Jabor A, Kautzner J. Utility of plasma D-dimer levels in the diagnosis of acute aortic dissection. Cor et Vasa 2013;55:e510-4.

10. Flanagan $L$, Bancroft $R$, Rittoo D. The value of d-dimer in the diagnosis of acute aortic dissection. International journal of cardiology 2007;118:e70-1.

11. Guan X, Gong M, Wang X, et al. Low preoperative fibrinogen level is risk factor for neurological complications in acute aortic dissection. Medicine 2018;97:e10830.

12. Meng CR, Zhang Q, Wang JL, Gu T, Zhang ZX. The role of fructosamine and hemoglobin levels in non-diabetic patients with thoracica cute aortic dissection. Int J Clin Exp Med 2016;9:8248-52.

13. Liu XT, He XW, Tan $R$, et al. High-density lipoprotein cholesterol and in-hospital mortality in patients with acute aortic dissection. Journal of Huazhong University of Science and Technology [Medical Sciences] 2016;36:364-7.
14. Sbarouni E, Georgiadou P, Marathias A, Panagiotakos D, Geroulanos S, Voudris V. Ischemia-modified albumin in acute aortic dissection. Journal of clinical laboratory analysis 2010;24:399-402.

15. Kalkan ME, Kalkan AK, Gündeş A, et al. Neutrophil to lymphocyte ratio: a novel marker for predicting hospital mortality of patients with acute type A aortic dissection. Perfusion 2017;32:321-7.

16. Lafçı G, Çiçek ÖF, Uzun HA, et al. Relationship of admission neutrophil-to-lymphocyte ratio with in-hospital mortality in patients with acute type-I aortic dissection. Turkish journal of medical sciences 2014;44:186-92.

17. Li G, Zhao L, Ma Y, et al. Platelet count to lymphocyte count ratio may predict mortality in Stanford type $B$ acute aortic dissection. Int J Clin Exp Med 2019;12:1922-8. 